\title{
Inhibition by $o$-Aminoazotoluene of the Incorporation of Certain Radioactive Amino Acids into Lipids of Mycobacterium smegmatis
}

\author{
By M. TSUKAMURA, S. MIZUNO AND S. TSUKAMURA \\ The Obuso National Sanatorium, Obu (near Nagoya), \\ Aichi-Prefecture, and the Department of Bacteriology, \\ Medical Faculty of Nagoya University, Nagoya, Japan
}

\begin{abstract}
SUMMARY
A carcinogenic substance, 0 -aminoazotoluene (AAT), inhibited the incorporation of $\left[1^{-14} \mathrm{C}\right]$ glycine and $\left[1^{14} \mathrm{C}\right]$ leucine into the lipid fraction of Mycobacterium smegmatis. It inhibited transiently the incorporation of $[1-14 \mathrm{C}]$ glutamic acid into lipids, but it did not inhibit the incorporation of $\left[1-{ }^{14} \mathrm{C}\right]$ acetate into lipids. AAT did not inhibit the incorporation into the protein and nucleic acid fractions of $\left[1-{ }^{14} \mathrm{C}\right]$ glycine, $\left[1-{ }^{14} \mathrm{C}\right]$ leucine, $\left[1-{ }^{-14} \mathrm{C}\right]$ glutamic acid, and $\left[1^{14} \mathrm{C}\right]$ acetate.
\end{abstract}

\section{INTRODUCTION}

Yoshida (1932, 1934 $a, b)$ demonstrated that $o$-aminoazotoluene (AAT) produced proliferation of hepatic tissue and hepatomas in mice. Biochemical observations on carcinogenesis, including reaction of the azo dyes with proteins, have been carried out by many investigators (reviews by Miller \& Miller, 1953; Rondoni, 1955; Busch, 1962; Reid, 1962). Recently we observed that the growth of mycobacteria was inhibited by low concentrations of AAT in chemically defined media, but that this inhibition was abolished in egg media. As the action of AAT on mycobacterial cells is of interest in relation to its action on the cells of higher organisms, we have studied biochemical changes produced in mycobacteria by AAT.

\section{METHODS}

Mycobacterium smegmatis strain Jucho was used throughout. The following radioactive compounds were employed for the study: $\left[1^{-14} \mathrm{C}\right]$ glycine (specific radioactivity, $57 \cdot 3 \mu \mathrm{c} . / \mathrm{mg}$.), DL- $\left[1^{-14} \mathrm{C}\right]$ leucine (specific radioactivity, $44 \cdot 0 \mu \mathrm{c} . / \mathrm{mg}$.), DL-[1-14 C]glutamic acid (specific radioactivity, $21 \cdot 0 \mu \mathrm{c} . / \mathrm{mg}$.), and sodium $\left[1{ }^{14} \mathrm{C}\right]-$ acetate (specific radioactivity, $148 \mu \mathrm{c} . / \mathrm{mg}$.); all supplied by the Radiochemical Centre, Amersham, Buckinghamshire.

The test organism was cultivated at $37^{\circ}$ for 5 days in a modified Sauton medium, in which sodium glutamate was substituted for asparagine. The bacteria were harvested, washed three times in saline, and the washed bacteria incubated in reaction mixtures containing a radioactive compound. At different times, the reaction mixtures were cooled in ice and centrifuged. The bacteria were washed once with a solution of $1 \%$ $(\mathrm{w} / \mathrm{v})$ glycine, $1 \%$ leucine, $1 \%$ sodium glutamate, or $1 \%$ sodium acetate. They were then washed three times in distilled water and fractionated according to the procedure of Schneider (1945). The method was described previously (Tsukamura, Tsukamura \& Mizuno, 1964).

Vol. 41, No. 3 was issued 21 January 1966 
M. Tsukamura, S. Mizuno and S. Tsukamura

Samples $(0 \cdot 2 \mathrm{ml}$.) of each fraction were placed in stainless steel planchets and heated to dryness. The radioactivity was measured by a $2 \pi$ gas flow counter and expressed as 'counts/minute/mg. dry weight organism' (the radioactivity in the sample was multiplied according to the amount of the fraction and divided by the dry weight). The radioactivity was recorded after subtracting the radioactivity at time 0.

Portions of the trichloroacetic acid (TCA)-soluble fractions were extracted five times with ethyl ether to remove the TCA and concentrated by heating under reduced pressure. Portions of the protein fractions were hydrolysed by heating in $6 \mathrm{~N}-\mathrm{HCl}$ at $100^{\circ}$ for $24 \mathrm{hr}$ and concentrated by heating. These concentrates were subjected to ascending paper chromatography, using Toyo filter paper no. 50 and solvents consisting of tertiary butanol + formic acid + water $(70+15+15$ by vol. $)$ and isobutanol + formic acid + water $\left(70+15+15\right.$ by vol.). The $R_{F}$ values given in this paper were obtained with the former solvent system unless it is specifically stated otherwise. The radioactivity in paper chromatograms was recorded on an automatic paper chromatogram scanner (Nihon Musen, Tokyo; running : $300 \mathrm{~mm}$./hr; recording : $150 \mathrm{~mm}$./hr; slit, $3 \mathrm{~mm}$.; range: 300 or 1000 counts $/ 5 \mathrm{sec}$.).

AAT (Takeda Chemical Co., Osaka) was dissolved in propyleneglycol at a concentration of $2 \mathrm{mg} . / \mathrm{ml}$. and $0.1 \mathrm{ml}$. samples of this solution were added to $4.0 \mathrm{ml}$. of the reaction mixtures. Thus, the final concentration in the reaction mixtures was $50 \mu \mathrm{g}$. AAT $/ \mathrm{ml}$., which was two to four times higher than the minimal inhibitory concentration. Control reaction mixtures contained $0 \cdot 1 \mathrm{ml}$. propyleneglycol without AAT.

\section{RESULTS}

Effect of $A A T$ on the incorporation of $\left[1-{ }^{14} \mathrm{C}\right]$ glutamic acid

AAT did not inhibit the incorporation of $\left[1-{ }^{-14} \mathrm{C}\right]$ glutamic acid into the protein fraction, but it inhibited incorporation into the lipid and nucleic acid fractions during the first $6 \mathrm{hr}$. The effects of the inhibition had disappeared after $24 \mathrm{hr}$ of incubation (Table 1).

Table 1. Effect of o-aminoazotoluene on the incorporation of $\left[{ }^{1-14} \mathrm{C}\right]$ glutamic acid into the cellular fractions of Mycobacterium smegmatis strain Jucho

\begin{tabular}{|c|c|c|c|c|c|}
\hline \multirow[b]{3}{*}{$\begin{array}{c}\text { Reaction } \\
\text { mixture }\end{array}$} & \multirow[b]{3}{*}{$\begin{array}{c}\text { Time } \\
\text { (hr) }\end{array}$} & \multicolumn{4}{|c|}{ Radioactivity as counts/min./mg. dry wt. bacteria } \\
\hline & & \multicolumn{4}{|c|}{ Fraction } \\
\hline & & $\begin{array}{c}\text { TCA- } \\
\text { soluble }\end{array}$ & Lipid & $\begin{array}{l}\text { Nucleic } \\
\text { acid }\end{array}$ & Protein \\
\hline Control & $\mathbf{3}$ & 1070 & 73 & 77 & 131 \\
\hline AAT & $\mathbf{3}$ & 502 & 49 & 40 & 65 \\
\hline Control & 6 & 740 & 159 & 102 & 152 \\
\hline AAT & 6 & 532 & 49 & 56 & 170 \\
\hline Control & $\mathbf{2 4}$ & 606 & 275 & 193 & 686 \\
\hline AAT & 24 & 302 & 226 & 207 & 805 \\
\hline
\end{tabular}

Reaction mixtures consisted of $4.0 \mathrm{ml}$. of $0.067 \mathrm{M}-$ phosphate buffer (pH 7.1) containing $35 \mathrm{mg}$. wet wt. bacteria/ml., 2.5 $\mu$ c. DL-[1-14C]glutamic acid/ml., $5 \mu \mathrm{g}$., sodium glutamate/ml., $125 \mu \mathrm{g}$. glucose $/ \mathrm{ml}$, and 0 or $50 \mu \mathrm{g}$. 0 -aminoazotoluene $/ \mathrm{ml}$. 
Effect of $A A T$ on the incorporation of $D L-\left[1-{ }^{14} C\right] l e u c i n e$

Incorporation of $\left[1^{14} \mathrm{C}\right]$ leucine into the lipid fraction was depressed in the presence of AAT. On the other hand, its incorporation into the protein fraction was not inhibited, but rather accelerated, by AAT (Table 2).

The only radioactive peak found in paper chromatograms of the TCA-soluble and protein fractions had an $\boldsymbol{R}_{F}(\mathbf{0 \cdot 8 0})$ identical to that of leucine, whether AAT was present or not.

Table 2. Effect of o-aminoazotoluene on the incorporation of ${ }^{D L}\left[1-{ }^{14} C\right]$-leucine into the cellular fractions of Mycobacterium smegmatis strain Jucho

\begin{tabular}{lccccr} 
& & & $\begin{array}{r}\text { Radioactivity as counts/min./mg., } \\
\text { dry wt. bacteria }\end{array}$ \\
Reaction & Time & TCA- & \multicolumn{4}{c}{ Fraction } \\
mixture & $(\mathrm{hr})$ & soluble & Lipid & acid & Protein \\
Control & 6 & 614 & 110 & 171 & 6,280 \\
AAT & 6 & 450 & 76 & 109 & 5,710 \\
Control & 24 & 545 & 520 & 348 & 10,800 \\
AAT & 24 & 588 & 325 & 337 & 17,900
\end{tabular}

Reactions mixture consisted of $4 \cdot 0 \mathrm{ml}$. of $0 \cdot 067 \mathrm{M}$-phosphate buffer (pH 7.1) containing $30 \mathrm{mg}$. wet wt. bacteria $/ \mathrm{ml}$., 2.0 $\mu \mathrm{c}$. DL-[1-14 $\mathrm{C}]$ leucine $/ \mathrm{ml}$., $5 \mu \mathrm{g}$. L-leucine $/ \mathrm{ml}$., $125 \mu \mathrm{g}$. glucose $/ \mathrm{ml}$., and 0 or $50 \mu$ g. $o$-aminoazotoluene $/ \mathrm{ml}$.

Table 3. Effect of o-aminoazotoluene on the incorporation of $\left[1-{ }^{14} \mathrm{C}\right]$ glycine into the cellular fractions of Mycobacterium smegmatis strain Jucho

\begin{tabular}{|c|c|c|c|c|c|}
\hline \multirow[b]{3}{*}{$\begin{array}{c}\text { Reaction } \\
\text { mixture }\end{array}$} & \multirow[b]{3}{*}{$\begin{array}{c}\text { Time } \\
\text { (hr) }\end{array}$} & \multicolumn{4}{|c|}{$\begin{array}{c}\text { Radioactivity as counts/min./mg. } \\
\text { dry wt. bacteria }\end{array}$} \\
\hline & & \multicolumn{4}{|c|}{ Fraction } \\
\hline & & $\begin{array}{l}\text { TCA- } \\
\text { soluble }\end{array}$ & Lipid & Nucleic acid & Protein \\
\hline $\begin{array}{l}\text { Control } \\
\text { AAT }\end{array}$ & $\begin{array}{l}\mathbf{3} \\
\mathbf{3}\end{array}$ & $\begin{array}{l}6,110 \\
6,380\end{array}$ & $\begin{array}{l}653 \\
736\end{array}$ & $\begin{array}{l}2,140 \\
3,090\end{array}$ & $\begin{array}{l}3,040 \\
7,070\end{array}$ \\
\hline $\begin{array}{l}\text { Control } \\
\text { AAT }\end{array}$ & $\begin{array}{l}6 \\
6\end{array}$ & $\begin{array}{l}3,700 \\
4,360\end{array}$ & $\begin{array}{l}920 \\
870\end{array}$ & $\begin{array}{l}4,680 \\
5,270\end{array}$ & $\begin{array}{r}6,970 \\
10,000\end{array}$ \\
\hline $\begin{array}{l}\text { Control } \\
\text { AAT }\end{array}$ & $\begin{array}{l}\mathbf{2 4} \\
\mathbf{2 4}\end{array}$ & $\begin{array}{l}6,840 \\
4,900\end{array}$ & $\begin{array}{l}4,600 \\
1,680\end{array}$ & $\begin{array}{l}17,300 \\
15,900\end{array}$ & $\begin{array}{l}37,000 \\
44,000\end{array}$ \\
\hline
\end{tabular}

Reaction mixtures consisted of $4.0 \mathrm{ml}$. of $0.067 \mathrm{M}$-phosphate buffer ( $\mathrm{pH} \mathrm{7 \cdot 1}$ ) containing $14 \mathrm{mg}$. wet wt. bacteria $/ \mathrm{ml} ., 2 \cdot 5 \mu \mathrm{c}$. $\left[{ }^{1-14} \mathrm{C}\right]$ glycine $/ \mathrm{ml}$., $5 \mu \mathrm{g}$. glycine $/ \mathrm{ml}$., $125 \mu \mathrm{g}$. glucose $/ \mathrm{ml}$., and 0 or $50 \mu$ g. o-aminoazotoluene/ml.

\section{Effect of $A A T$ on the incorporation of $\left[1-{ }^{14} C\right]$ glycine}

[1-14C]Glycine was incorporated into the lipid, nucleic acid and protein fractions. The incorporations into the nucleic acid and protein fractions were not inhibited by AAT. On the other hand, the incorporation into the lipid fraction was inhibited by AAT, and showed most clearly after $24 \mathrm{hr}$ of incubation (Table 3). 
A radioactive peak, identified as serine $\left(R_{F} \mathbf{0 \cdot 3 6 - 0 \cdot 3 7 )}\right.$ by comparison with authentic serine, was found in paper chromatograms of the TCA-soluble and protein fractions. Since other radioactive peaks were not found in the paper chromatograms, presumably glycine was converted into serine and incorporated into protein (Fig. 1). However, in what form glycine is incorporated into lipids remains unknown.

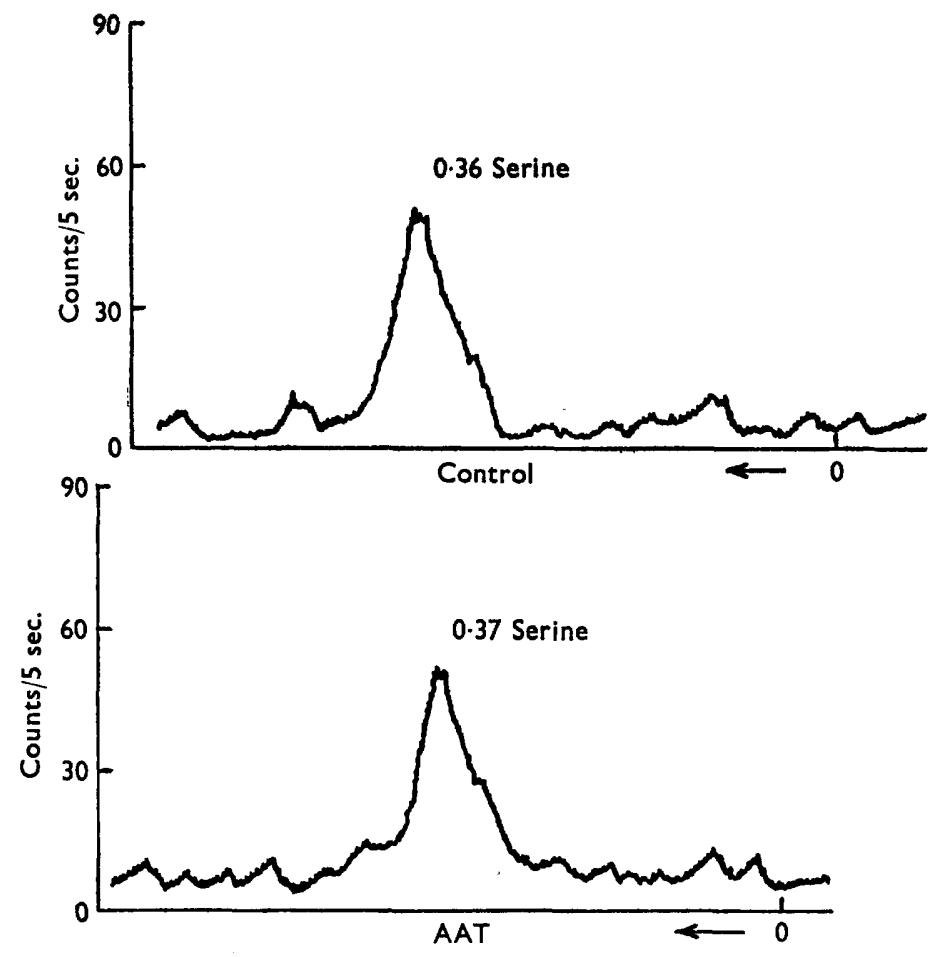

Fig. 1. Radioactivity in paper chromatograms of the acid hydrolysates of the protein fraction obtained after incubation with $\left[1-{ }^{14} \mathrm{C}\right] \mathrm{glycine}$ for $24 \mathrm{hr}$ in the presence and absence of AAT.

Table 4. Effect of o-aminoazotoluene on the incorporation of sodium $\left[1{ }^{14} \mathrm{C}\right]-$ acetate into the cellular fractions of Mycobacterium smegmatis strain Jucho

\begin{tabular}{lccccc}
\multicolumn{4}{c}{$\begin{array}{c}\text { Radioactivity as counts/min./mg., } \\
\text { dry wt. bacteria }\end{array}$} \\
Reaction & Time & $\overbrace{\text { TCA- }}$ Fraction \\
mixture & $(\mathrm{hr})$ & soluble & Lipid & $\begin{array}{c}\text { Nucleic } \\
\text { acid }\end{array}$ & Protein \\
Control & 6 & $\mathbf{3 0 0}$ & $\mathbf{6 9 7}$ & 146 & 830 \\
AAT & 6 & $\mathbf{5 0 5}$ & $\mathbf{7 0 5}$ & 100 & $\mathbf{7 2 5}$ \\
Control & $\mathbf{2 4}$ & $\mathbf{4 9 2}$ & $\mathbf{9 5 8}$ & $\mathbf{1 8 8}$ & $\mathbf{1 1 3 0}$ \\
AAT & $\mathbf{2 4}$ & $\mathbf{4 7 4}$ & $\mathbf{8 8 8}$ & $\mathbf{1 7 1}$ & $\mathbf{1 0 7 0}$
\end{tabular}

Reaction mixtures consisted of $4.0 \mathrm{ml}$. of $0.067 \mathrm{M}-$ phosphate buffer (pH 7.1) containing $70 \mathrm{mg}$. wet wt. bacteria $/ \mathrm{ml}$., $1.0 \mu \mathrm{c}$. sodium $\left[1-{ }^{-14} \mathrm{C}\right]$ acetate $/ \mathrm{ml}$., $100 \mu \mathrm{g}$. ammonium chloride $/ \mathrm{ml}$., and 0 or $50 \mu$ g. 0 -aminoazotoluene $/ \mathrm{ml}$. 


\section{Effect of $A A T$ on the incorporation of sodium $\left[1-{ }^{14} \mathrm{C}\right]$ acetate}

$\left[{ }^{-14} \mathrm{C}\right]$ Acetate was incorporated into the lipid, nucleic acid and protein fractions. Almost no inhibitory effect of AAT on incorporation into these fractions was found (Table 4).

\section{DISCUSSION}

Incorporation of $\left[1^{-14} \mathrm{C}\right]$ glutamic acid, $\left[1^{-14} \mathrm{C}\right]$ leucine, $\left[1^{-14} \mathrm{C}\right]$ glycine, and $\left[1^{-14} \mathrm{C}\right]-$ acetate into the cellular fractions was observed both in the presence and absence of AAT. The concentration of AAT used was 2 to 4 times higher than the minimal growth-inhibitory concentration. Since the generation time of this organism was more than ten times longer than that of Escherichia coli, cultures were observed for a period of $24 \mathrm{hr}$.

The results showed that AAT inhibited the incorporation of $\left[1^{14} \mathrm{C}\right]$ glutamic acid, $\left[1^{-14} \mathrm{C}\right]$ leucine and $\left[{ }^{-14} \mathrm{C}\right]$ glycine into the lipid fraction, the incorporation of the latter two amino acids being inhibited more markedly. On the other hand, incorporation of $\left[1^{-14} \mathrm{C}\right]$ acetate into the same fraction was not inhibited significantly by this agent.

It has been reported recently that serine is incorporated into lipids of Escherichia coli in the form of phosphatidylserine (Kanfer \& Kennedy, 1964). Although it has been demonstrated in the present study that glycine is converted to serine, it remains to be tested in future whether or not glycine is incorporated into lipids via serine.

It was noted that AAT did not inhibit the incorporation of glutamic acid, leucine, glycine, or acetate into the protein and nucleic acid fractions.

The authors wish to express their appreciation to Professor K. Ogasawara for his kind advice. They thank also Dr R. Katsunuma for his kind help for this study.

\section{REFERENCES}

Busch, H. (1962). An Introduction to the Biochemistry of the Cancer Cell, p. 197. New York: Academic Press.

Kanfer, J. \& KenNedy, E. P. (1964). Metabolism and function of bacterial lipids. II. Biosynthesis of phospholipids in Escherichia coli. J. biol. Chem. 239, 1720.

Mrller, J. A. \& Milder, E. C. (1953). The carcinogenic dyes. Advanc. Cancer Res. 1, 339.

REID, E. (1962). Significant biochemical effects of hepatocarcinogens in the rat: a review. Cancer Res. 22, 398.

Rondoni, P. (1955). Some aspects of carcinogenesis. Advanc. Cancer Res. 3, 171.

Schneider, W. C. (1945). Phosphorus compounds in animal tissues. I. Extraction and estimation of desoxypentose nucleic acid and of pentose nucleic acid. J. biol. Chem. $161,293$.

Tsukamura, M., Tsukamura, S. \& Mizuno, S. (1964). Mode of action of chromomycin A3 on a Mycobacterium. J. Antibiot. Tokyo, A, 17, 246.

Yoshida, T. (1932). Hepatoma induced by feeding with 0 -aminoazotoluene. Proc. imp. Acad. Japan, 8, 464.

Yoshida, T. (1934a). Studies on the course of the development of experimental production of hepatoma induced by ortho-aminoazotoluol. Gann, 28, 225.

YoshidA, T. (1934b). Experimental production of tumours by subcutaneous injection of an olive oil solution of 0 -aminoazotoluene. Gann, 28, 441 . 